present generating capacity. Although, according to Energy Minister Moda'i, electricity can still be generated more cheaply using fossil-fuelled power stations, granted the need for such a canal, powerproduction might make it economic.

One early exponent of such a canal was American pioneer of land conservation, William Clay Lowdermilk. In 1939, Lowdermilk formulated an "eleventh commandment" for the future state of Israel. This reads, in part: "Thou shalt safeguard thy fields from soil erosion, thy living waters from drying up ....". This summer's drought has made it imperative that this "commandment" should be extended to include not only the "living" waters of the Jordan and Sea of Galilee but also those of the Dead Sea.

Vera Rich

\section{UK plans nuclear expansion}

BRITAIN'S Conservative government is expected to announce details of a $£ 10 \mathrm{bn}$ nuclear expansion programme within the next few weeks. The plan will involve building up to 20 nuclear reactors to supply half Britain's electricity needs by the year 2000. The Conservative cabinet is unanimous in its support for nuclear power, the only disagreements being over reactor type.

At present it is believed the American pressurised water reactor of the type involved in the Harrisburg accident is the leading candidate because it can be brought on line in five years, half the time needed by the advanced gas cooled reactor. Two public inquiries will be held before the plan can be enacted. One is a planning inquiry about the siting of the PWR, the other a full public inquiry about the necessity for a fast breeder reactor for Britain's nuclear future. Although strong opposition plan to counter it. "They will wait and see how effective the opposition is before taking counter measures"' a Department of Energy spokesperson told Nature.

USSR questions nuclear safety: For the first time, the Communist Party has published an article on negative environmental effects of nuclear power. The article, in Kommunist, the party's theoretical journal, was co-authored by Nikolai Dolezhal, a prominent nuclear scientist, and Yurii Kroyakim, a relatively unknown economist. It questions the amount of valuable agricultural land that would be used, the effect on water supplies and the difficulties of storing nuclear wastes.

The article stresses that the sheer scale of the programme involving an expansion from the present level of 10 million $\mathrm{kW}$ to over 110 million $\mathrm{kW}$ by 1990 plus the construction of nuclear power stations in western Soviet cities as sources if district power heating would encroach considerably on agricultural land. Previous Soviet comment has characterised the anti-nuclear movement as being inspired by oil companies anxious to preserve their market position.

French demo blocks fuel: In a militant demonstration against nuclear fuel reprocessing, French trade unionists and environmentalists held up the unloading of Nearly 2,000 demonstrators met the ship chartered by British Nuclear Fuels Ltd when it docked at Cherbourg on 9 October with its cargo for reprocessing at nearby $\mathrm{La}$ Hague.

Demonstrators blocked a railway siding, severed an electric cable and put a crane out of action in a successful attempt to block the unloading. The Socialist Party and the socialist trade union federation the CFDT are demanding a national debate to prevent France from becoming "the nuclear dustbin of the world".

Waste disposal plan could take a decade: An independent waste disposal plan produced by the state of California has caught the nuclear industry by suprise. The plan calls for simulated waste to be placed in experimental vaults 1000 metre under ground in variety of geological formations. Measurements would be taken on migration rates as a function of rock type, temperature, depth, and pressure and the findings compared to theoretical predictions.

The entire process would take ten years and is recognised to be the only valid way to assess present underground storage plans. The federal government accused the state government of ignoring national energy policy and of failing to keep Washigton informed. The move is widely regarded as a show of strength by the anti-nuclear movement and is expected to give a boost to California governor Jerry Brown's campaign for the presidency.

Protestors march in Bonn: In the largest demonstration since the early 1930s, protestors demanded an immediate end to the development of nuclear power is West Germany. Individual columns stretched more than $2 \frac{1}{2}$ miles as 100,000 activists including representatives from the US Austrian, Danish, Dutch, French and Swedish anti-nuclear movements converged on Hofgarten park in central Bonn last Sunday. Demonstrators gave a standing ovation to a speech from Kathy McCaughin of the Harrisburg Citizens Action Group who called for a stop to "the nuclear madness now". Trade union speakers were applauded when they said that more jobs would be created by alternative technology instead of nuclear power.

Joe Schwartz
15 tons of spent nuclear fuel from Japan.

\section{Syrians blast UNCSTD over power politics}

SYRIA'S delegation to UNCSTD returned home unsatisfied and a little angry. "We know that the problems of development cannot be solved with one conference, but at least we could have made a start", says Dr A W Chahid, Director of the Centre for Scientific Studies and Research in Damascus and a leading member of the Syrian delegation.

The future for the developing countries after UNCSTD, says Dr Chahid, is " just as hazy as it was before. We came back from Vienna even more convinced of the inherent biases and injustices of the existing scientific and technological order in the world".

Most of the developing countries were not prepared for the tight, hard-nosed negotiations and power play that was conducted by the developed countries at UNCSTD. Dr Chahid is particularly critical of the petty politics and the infighting of the European Community countries. "The attitude of the Nine to the proposed Development Fund was quite pathetic", he says. (A fund of $\$ 2$ billion to 1985 proposed by the Group of 77 was cut to $\$ 250$ million to 1981 .) The Nine were also responsible for frustrating the good intentions of "the Nordic Group which was quite forthcoming and ready to make a reasonable contribution to the fund".

Dr Chahid thinks it was unfortunate that the Group of 77 was dominated by countries that are at the top of the development continuum. India, Brazil, Yugoslavia and other members of the 'Group of 27' of the Group of 77 who took part in the negotiations have a reasonably developed scientific and technological infra-structure. "It is these countries which stand to gain most out of the few achievements of UNCSTD".

But what about the really poor countries that suffer from the "small country problems", that do not have even the tiniest form of science and technology infrastructure? "What do they get out of UNCSTD?" asks Dr Chahid. "We must ensure that they get the lion's share of the Development Fund, little though it is".

The power and coordinating ability of the Group of 77 will be tested to the full in the setting up of the UN intergovernmental committee that will administer the Development Fund. Dr Chahid argues that if all members of the Group of 77 took an active interest in the intergovernmental committee and if there was "a very strong Group of 77 representation on the Committee", it may be possible to steer development in the Third World's favour.

However, Dr Chahid points out that many developing countries, including Syria, do not have a representative in New York. 